九州大学学術情報リポジトリ

Kyushu University Institutional Repository

Effect of Sintering Time on Microstructure and Mechanical Properties of Hydroxyapatite Porous Materials for Bone Tissue Engineering Application

Phanny, Yos

Interdisciplinary Graduate School of Engineering Sciences, Kyushu University

Todo, Mitsugu

Research Institute for Applied Mechanics, Kyushu University

https://doi.org/10.5109/1495025

出版情報: Evergreen. 1 (2)，pp. 1-4，2014-09. Green Asia Education Center バージョン：

権利関係 : 


\title{
Effect of Sintering Time on Microstructure and Mechanical Properties of Hydroxyapatite Porous Materials for Bone Tissue Engineering Application
}

\author{
Yos Phanny ${ }^{1}$, Mitsugu Todo ${ }^{2 *}$ \\ ${ }^{1}$ Interdisciplinary Graduate School of Engineering Sciences, Kyushu University, Japan \\ ${ }^{2}$ Research Institute for Applied Mechanics, Kyushu University, Japan \\ *Author to whom correspondence should be addressed, \\ E-mail: todo@riam.kyushu.ac.jp
}

(Received July 7, 2014; accepted August 6, 2014)

\begin{abstract}
Continuous porous structures of bioactive ceramics such as hydroxyapatite (HA) have been used as scaffolds in bone tissue engineering. Sintering time is one of the main factors to obtain optimum mechanical properties of such bioceramic scaffolds. In the present study, the template method was utilized to fabricate HA scaffolds sintered at $1300^{\circ} \mathrm{C}$. Sintering time was varied from 30 minutes to 20 hours in order to understand the effects of sintering time on the microstructures and compressive mechanical properties of HA scaffolds. It was found the compressive mechanical properties were greatly improved with increasing sintering time. This is mainly due to the strengthening of HA frame structure with increase of grain size and decrease of microdefects such as pores.
\end{abstract}

Keywords: scaffold, template method, hydroxyapatite, compressive properties

\section{Introduction}

Tissue engineering has been considered as one of the key technologies to cure damaged organs and tissues instead of doing pharmacological treatment, transplantation, or implantation of artificial organs or tissues ${ }^{1)}$. Tissue engineering is an interdisciplinary field that applies the principles of engineering and life science to the development of biological substitutes which are able to restore, maintain, or improve function of tissues. In bone tissue engineering, scaffold plays an important role for regenerating artificial bone tissues in vitro as the matrix for tissue formation and is required to have three-dimensional porous structure with high porosity, pore interconnectivity, uniform pore distribution, surface properties permitting cell adhesion, differentiation, non-cytotoxicity and osteoconductivity ${ }^{2-5)}$. In order to develop porous structural scaffolds, different kinds of fabrication method such as use of organic porosifiers ${ }^{6-7)}$, sponge template ${ }^{8)}$, foaming ${ }^{9)}$, and freeze-drying ${ }^{10)}$ have been applied. Among which, the template method using polyurethane foam as template is known to produce a three dimensional fully interconnecting porous structure similar to spongy bone.

Hydroxyapatite (HA) is one of the most popular bioceramics used for bone tissue engineering because its chemical structure is very similar to carbonate apatite which is the major inorganic component of bone ${ }^{11,12)}$ and is also known to have very good osteoconductivity and biocompatibility $^{13,14)}$. Many studies have been performed to understand the fundamental properties of HA scaffolds. For example, the mechanical and biological properties of porous HA scaffolds ${ }^{15}$, and the biocompatibility and cells activities of HA scaffolds were investigated under in vivo and in vitro conditions ${ }^{16-19)}$. However, effects of sintering time, which is one of the main factors in the fabrication process, on the microstructures and mechanical properties of porous HA scaffolds have not been clarified yet.

The objective of this work is therefore to characterize the effects of sintering time on the compressive mechanical properties of a porous HA scaffold developed for bone tissue engineering applications. The specimens with continuous porous structures were fabricated using the sponge template method and sintered at $1300^{\circ} \mathrm{C}$ with different sintering time from 30 minutes to 20 hours. The effects of sintering time on the microstructures and mechanical properties were then evaluated. The relationship between the mechanical performance and structural factors was also discussed to understand the mechanism of strengthening.

\section{Materials and methods}

\subsection{Materials and fabrication}

The specimens of HA porous scaffold were made by the template method with a polyurethane (PU) sponge template. HA slurry was prepared from a commercial 
micro-HA powder (SP-1, Sangi Co.Ltd.) mixed with poly vinyl alcohol (PVA: $\left.\left(\mathrm{CH}_{2} \mathrm{CHOH}\right)_{\mathrm{n}}\right)\left(165-17915, M_{w}\right.$ $=1500-1800 \mathrm{~g} / \mathrm{mol}$, Wako Pure Chemical Industries, Ltd.) solution of $5 \mathrm{wt} \%$, with the ratio of $1: 1$ (1g HA mix with $1 \mathrm{ml}$ PVA solution) using a centrifuge medium. PU sponge templates (HR-40, Bridgestone) cut into $1 \times 1 \times 1 \mathrm{~cm}^{3}$ cubic shape were immersed in the slurry. The PU templates with HA-PVA slurry were fully compressed to remove excess slurry and to disperse the slurry uniformly. The immersed templates were dried at $60^{\circ} \mathrm{C}$ for 24 hours. The dried templates were then heated at $400^{\circ} \mathrm{C}$ for 6 hours with a rate of $10^{\circ} \mathrm{C} / \mathrm{min}$ to remove the PU sponge completely and then sintered at $1300^{\circ} \mathrm{C}$ for different times (30 minutes, 1 hour, 2 hours, 3 hours, 5 hours, 10 hours, 15 hours and 20 hours) to solidify the scaffold structures.

\subsection{SEM and XRD}

HA scaffold morphology was investigated for each type of samples by a filed-emission scanning electron microscopy (FE-SEM S-4100, Hitachi, Ltd.). Samples were coated by a thin layer of $\mathrm{Pt} / \mathrm{Pd}$ using a sputter coater (Ion Sputter E-1030, Hitachi, Ltd.) and then observed by FE-SEM. For each fabrication condition, an average grain size was estimated using three FE-SEM images with use of the intercept method with 5 vertical lines. Effect of sintering time on the grain size was then examined.

Sample was grinded into fine powder for XRD characterization to analyze the phase stability. X-Ray diffractometer (Rigaku RINT-TTR III) was used and data were collected over the range of $2 \theta=20-40^{\circ}$.

\subsection{Mechanical testing}

Compressive mechanical tests were performed using a compact tabletop testing machine (EZTest, Shimadzu Co., Ltd.) equipped with $500 \mathrm{~N}$ load cell and at a crosshead speed of $1 \mathrm{~mm} / \mathrm{min}$. Elastic modulus was calculated from the initial slope of stress-strain curve. Compressive strength was also evaluated from the peak stress value of stress-strain curve.

\section{Results}

FE-SEM images of porous structure and grain distribution are shown in Fig.1. Three-dimensional and fully interconnected porous structures were obtained and the pore size was ranged between 100 to $500 \mu \mathrm{m}$. It is clearly seen that longer sintering time improved the micro-grain structure of HA scaffold with packed and dense grain boundaries.

Average grain size is shown as a function of sintering time in Fig.2. The grain size increased rapidly to about 4 $\mu \mathrm{m}$ for the first 3 hours and then gradually increased up to around $5 \mu \mathrm{m}$ at 20 hours.

XRD patterns of HA scaffolds and HA powder are shown in Fig.3. It is understood that peaks related to HA chemical structure were only observed and therefore no phase change was occurred under the sintering condition
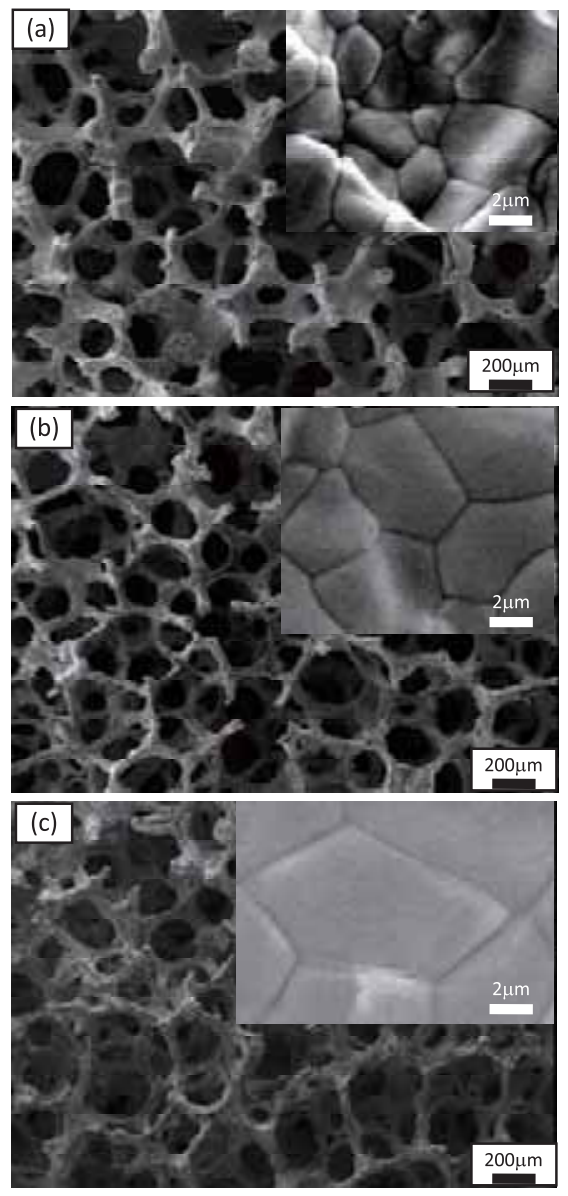

Fig. 1. FE-SEM images of HA scaffolds sintered at $1300^{\circ} \mathrm{C}$ for: (a) 1 hour, (b) 5hours and (c) 20 hours. The images on top right exhibit grain shape observed on the surface of strut.

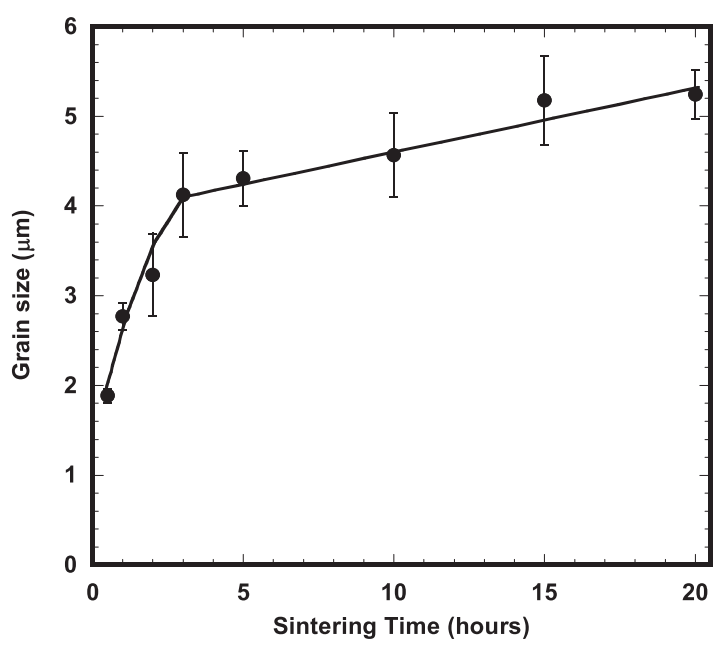

Fig. 2. Variation of average grain size as a function of sintering time. 


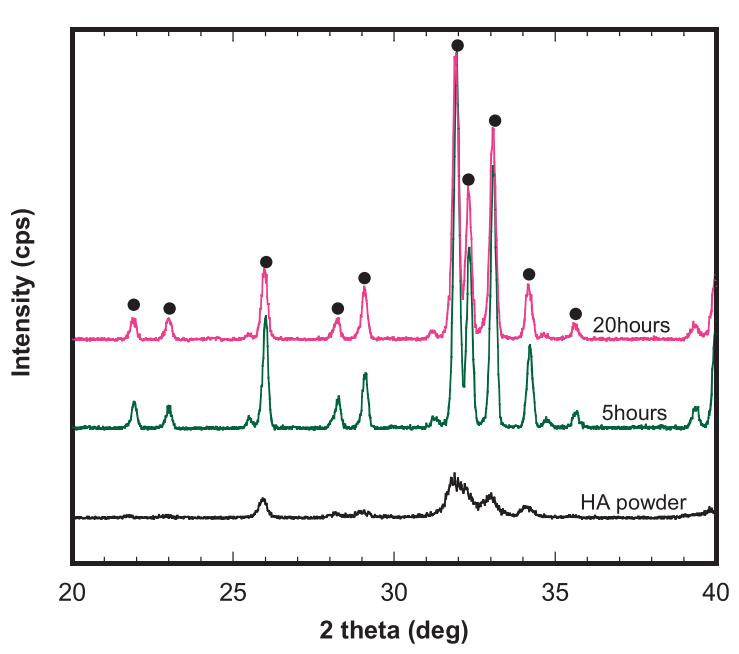

Fig. 3. X-ray diffraction patterns of: HA scaffolds and HA powder, $(\bullet)$ HA.

used in this study.

Variation of elastic modulus is shown as a function of sintering time in Fig.4.Elastic modulus increased from about $0.7 \mathrm{MPa}$ at the first 30 minute to about $1.2 \mathrm{MPa}$ at the end of sintering time of 20 hours. Elastic modulus almost linearly increased in the first few hours and then remained steady after 5 hours. Variation of compressive strength is shown as a function of sintering time in Fig.5. The strength significantly increased in the first 3 hours and then slowly increased up to about $43 \mathrm{kPa}$ at 20 hours.

\section{Discussion}

As shown in Fig.1, HA scaffolds possessed three-dimensional and fully interconnecting porous structures with proper pore size greater than $100 \mu \mathrm{m}$ which are known to be one of requirements for development of bone, soft tissue, cell attachment, proliferation and cell migration [2-5]. The microstructural analysis indicated that sintering process may be completed for sintering time of about 3 hours to 5 hours, with inducing coalescence, packed and dense arrangement of HA grains on the framework of the scaffolds (Figs.1(b) and (c)). It is noted that there was no micro-pores existing at the HA inter-grains on the strut structures. In Fig.2, longer sintering time resulted in greater grain size due to grain growth. This result corresponded to the report given in Ref.20, where densified HA samples were prepared by uniaxial pressed fine HA precursor sintered at $1200^{\circ} \mathrm{C}$ up for 22 hours.

The effective improvement of elastic modulus and compressive strength (Figs.4 and 5) is thought to strongly corelated with the microstructure, i.e. the packed and dense morphology of grains with existence of microdefects at the grain interfaces. FE-SEM micrographs of fracture portion of two specimens

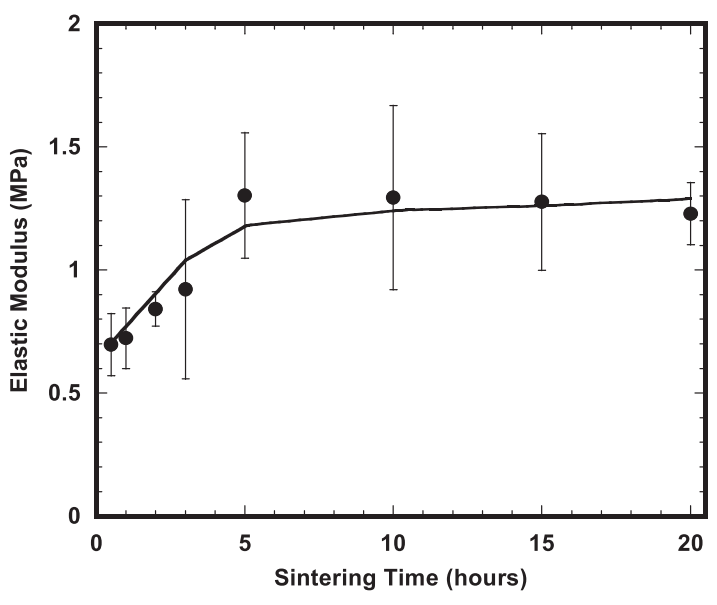

Fig. 4. Variation of elastic modulus of HA porous materials sintered at $1300^{\circ} \mathrm{C}$ as function of sintering time.

sintered for 30 minutes and 20 hours are shown in Fig.6. It is clearly seen that for the short sintering time, the strut of the HA scaffold contained micro-pores at the grain interfaces, while for the longer sintering time, no such defects were observed. This structural difference obviously affected the variational behavior of fracture property. It is also worth noting that the hollow structures with triangle shape indicate that the space was previously occupied by PU sponge structure which was burned out in the sintering process. This kind of hollow structure also greatly affects the compressive properties and usually tend to degrade the properties.

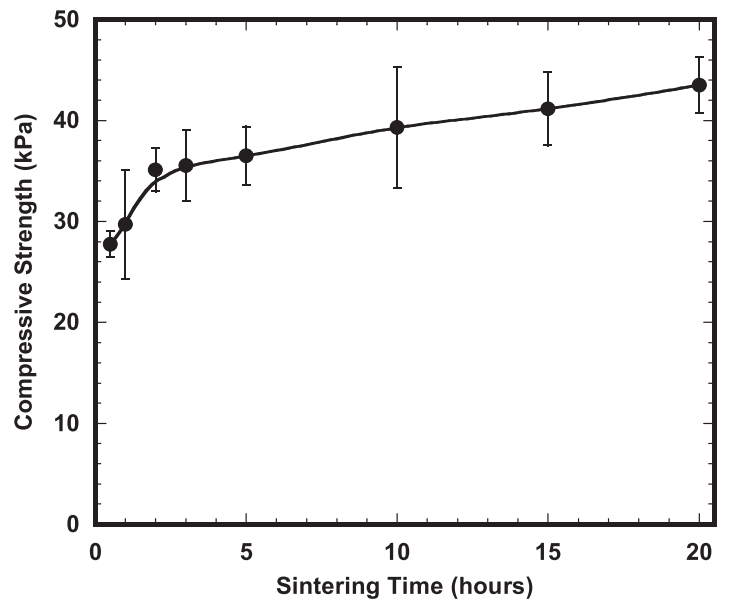

Fig. 5. Variation of compressive strength of HA porous materials sinter at $1300^{\circ} \mathrm{C}$ as function of sintering time. 


\section{Conclusions}

In this work, the effects of sintering time on the microstructures and compressive mechanical properties of HA scaffolds developed for bone tissue engineering application were investigated and the conclusions were obtained as follow:

(1) Packed and dense morphology of HA grain on the strut structure was achieved and HA grain growth occurred with prolonging sintering time up to 20 hours.

(2) Compressive mechanical properties such as elastic modulus and strength increased significantly under the condition of sintering time from 30 minutes to 3 hours and became almost steady afterwards up to 20 hours due to the improvement of micro-structure of framework.

(3) From view points of mechanical properties and productability, proper sintered time at $1300^{\circ} \mathrm{C}$ is 3 hours to 5 hours to confirm the completion of sintering process and optimized mechanical and structural properties.
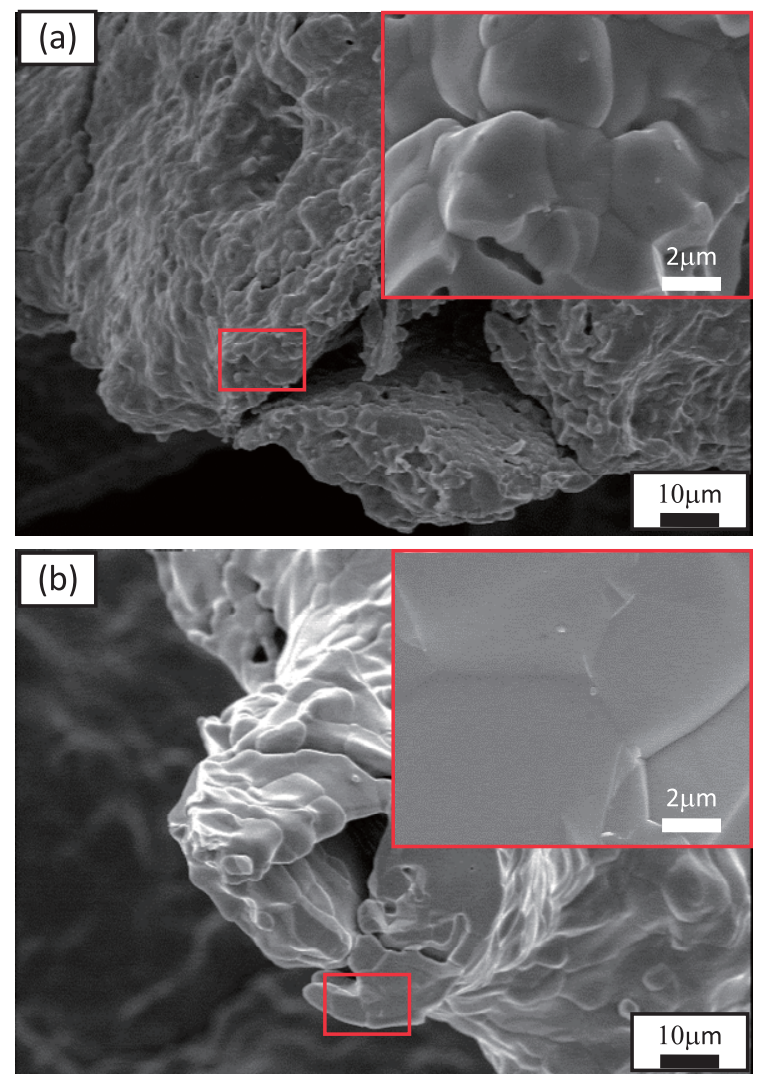

Fig. 6. FE-SEM micrographs of fracture region of HA scaffolds sintered at $1300^{\circ} \mathrm{C}$ for: (a) 30 minutes and (b) 20 hours

\section{References}

1) N. Sarvazyan, Cell and Tissue Engineering, ed. by B.
Obradović, Springer, Berlin Heidelberg, p.1-8 (2012).

2) S. -H. Lee and H. Shin, Adv. Drug Deliv. Rev., 59, 339 (2007).

3) D. W. Hatmacher and A. J. Garcia, Gene, 347, 1 (2005).

4) R. Langer and J. P. Vacanti, Sci., 260, 920 (1993).

5) A. J. Salgado, O. P. Coutinho and R. L. Reis, Macromol. Biosci., 4, 743 (2004).

6) I. H. Arita and V. M. Castano, J.Mater. Sci.-Mater. Med., 6, 19 (1997).

7) D.-M. O. Liu, J.Mater. Sci. -Mater. Med., 8, 227 (1995).

8) Y. Phanny and M. Todo, Key Eng. Mater., 529-530, 447 (2013).

9) D. L. Harris, B. -S. and D. J. Mooney, J. Biomed. Mater. Res., 42, 396 (1998).

10) K. Whang, K. E. Healy, D. R. Elenz, K. E. Nam, D. C. Tsai, C. H. Thomas, G. W. Nuber, F. H. Glorieux, R. Travers and S. M. Sprague, Tissue Eng., 5, 35 (1999).

11) Z. L. Raquel, Prog. Cryst. Growth Charact. Mater., 4, 1 (1981).

12) A. S. Posner and F. Betts, Acc. Chem. Res., 8, 273 (1975).

13) J. Werner, B. Linner-Krčmar, W. Friess and P. Greil, Biomaterials, 23, 4285 (2002).

14) J. R. Woodard, A. J. hilldore, S. K. Lan, C. J. Park, A. W. Morgan, J. A. C. Eurell, S. G. Clark, M. B. Wheller, R. D. Jamison and J. J. Wagoner Johnson, Biomaterials, 28, 45 (2007).

15) G. Tripathi and B. Basu, Ceram. Int., 38, 341 (2012).

16) L. Cerroni, R. Filocamo, M. Fabbri, C. Piconi, S. Caropreso and S. G. Condò, Biomol. Eng., 19, 119 (2002).

17) H. Wang, Y. Li, Y. Zuo, J. Li, S. Ma and L Cheng, Biomaterials, 28, 3338 (2007).

18) J. L. Moreau and H. H. K. Xu, Biomaterials, 30, 2675 (2009).

19) M. Tadokoro, K. Kawate, H. Yajima, Y. Takakura and H. Ohgushi, Artif. Organs, 6, 474 (2009).

20) K. C. B. Yeong, J. Wang and S.C. Ng, Mater. Lett., 38, 208 (1999). 